\title{
EL DERECHO DEL OTRO PROGENITOR AL DISFRUTE DEL PERMISO POR NACIMIENTO DE HIJO RECONOCIDO EN CONVENIO COLECTIVO TRAS LA ENTRADA EN VIGOR DEL REAL DECRETO-LEY 6/2019. A PROPÓSITO DE LA STS DE 27 DE ENERO DE 2021
}

\author{
Josep Moreno Gené ${ }^{1}$ \\ Profesor titular de Derecho del Trabajo y de la Seguridad Social \\ Universitat de Lleida
}

\begin{abstract}
La supresión del permiso por nacimiento de hijo previsto hasta el momento en el artículo 37.3.b) ET ha planteado un interesante debate sobre la vigencia de diferentes cláusulas incorporadas a numerosos convenios colectivos que recogían y, en no pocas ocasiones, mejoraban, el referido permiso por nacimiento de hijo y, en particular, sobre si las mismas quedaban sin vigencia tras el Real Decreto-Ley 6/2019 o si, por el contrario, los trabajadores aún podían acudir a las mismas para disfrutar del permiso por nacimiento de hijo, de forma acumulada a la correspondiente suspensión del contrato por nacimiento prevista a tal efecto para el otro progenitor. Precisamente, en la sentencia de 27 de enero de 2021 objeto de este comentario, el Tribunal Supremo aborda por primera vez esta cuestión.
\end{abstract}

The suspension of the leave due to birth of a child envisaged to date in Artículo 37.3.b) ET has given rise to an interesting debate on the validity of various clauses introduced into numerous collective wages agreements which included and, in many cases, improved on the aforementioned leave due to the birth of a child and, in particular, on whether these clauses were no longer valid following Royal Decree-Law 6/2019 or whether, on the contrary, the workers could still resort to them to enjoy the leave due to the birth of a child, before enjoying the corresponding suspension of the contract envisaged to this end for the other parent. The Supreme Court tackles this issue for the first time precisely in the judgement of 27 January 2021 to which this comment refers.

IUSLabor 2/2021, ISSN 1699-2938, p. 288-315

DOI. 10.31009/IUSLabor.2021.i2.10

Fecha envío: 26.3.2021| Fecha aceptación: 10.4.2021

\footnotetext{
${ }^{1}$ El autor es miembro del grupo de investigación consolidado reconocido por la Generalitat de Cataluña "Social and Business Research Laboratory" (SBRLab). Ref. 2017 SGR 1572.
} 
Tittle: The other parent's right to enjoy leave due to birth of a child recognized in the collective wages agreement since royal decree-law 6/2019 came into force. For the purpose of the STS of January 27, 2021

Palabras clave: permiso por nacimiento de hijo, suspensión del contrato por nacimiento, convenio colectivo, igualdad y no discriminación

Keywords: leave due to birth of a child, suspension of contract due to birth, collective wages agreement, equality and non-discrimination

\section{Sumario}

1. La equiparación de la duración de la suspensión del contrato por nacimiento de hijo correspondiente al otro progenitor a la prevista para la madre biológica y la paralela eliminación del permiso por nacimiento de hijo previsto en la ley

2. La admisión de la acumulación del permiso por nacimiento de hijo previsto en la negociación colectiva con la suspensión del contrato de trabajo por nacimiento de hijo introducida por el Real Decreto-Ley 6/2019: el criterio de la Audiencia Nacional y de algún Tribunal Superior de Justicia

3. La incompatibilidad del permiso por nacimiento de hijo previsto en la negociación colectiva con la suspensión del contrato de trabajo por nacimiento de hijo tras el Real Decreto-Ley 6/2019: el criterio del Tribunal Supremo

4. La subsunción del permiso por nacimiento de hijo en la suspensión del contrato por nacimiento y sus efectos en los permisos previstos en convenio colectivo: ¿Zanja el Tribunal Supremo la cuestión?

5. Bibliografía 


\section{La equiparación de la duración de la suspensión del contrato por nacimiento de hijo correspondiente al otro progenitor a la prevista para la madre biológica y la paralela eliminación del permiso por nacimiento de hijo previsto en la ley}

Entre las causas en que históricamente se ha apoyado la discriminación laboral de las mujeres, sin lugar a dudas, cabe destacar la división de roles tradicionalmente asignados a los hombres y mujeres, de modo que mientras que se ha considerado que los primeros son los responsables de sustentar económicamente a la familia, correspondiéndoles en consecuencia una función productiva, a las segundas se les ha atribuido una función reproductiva y de cuidado del hogar. En este punto, la maternidad y las "responsabilidades familiares" han supuesto y siguen suponiendo un importante obstáculo para la integración, promoción y estabilidad laboral de las mujeres, puesto que son percibidas por los empresarios como factores negativos que pueden repercutir en un menor rendimiento en el trabajo con respecto al hombre y generar problemas en la organización empresarial.

En este contexto, si realmente se quiere lograr la efectiva igualdad entre mujeres y hombres, deben adoptarse medidas que rompan con el referido esquema de reparto de roles sexuales entre ambos colectivos, de modo que los hombres asuman cada vez mayores "responsabilidades familiares" hasta equipararse en este punto con las mujeres 2 . A tal efecto, si mujeres y hombres asumieran con idéntica o similar intensidad las referidas "responsabilidades familiares", esta circunstancia ya no podría ser tomada en

\footnotetext{
${ }^{2}$ En esta dirección, FernáNDEZ Collados, María Belén, "El permiso por paternidad como medida de conciliación de la vida familiar y laboral: aspectos críticos y propuestas de mejora", Revista Española de Derecho del Trabajo y de la Seguridad Social, no 139, 2008, p. 640, afirma que "si realmente se quiere lograr la efectiva igualdad entre mujeres y hombres, las medidas deben atender más que a la conciliación de la vida familiar y laboral, a romper definitivamente con el trasnochado pero vigente esquema social del reparto de roles sexuales, para lo que debe ponerse el acento en el fomento de la asunción por los varones de los "deberes familiares". Se muestran de la misma opinión, NúÑEZ-CORTÉS CONTRERAS, Pilar y GARRIGUES GIMÉNEZ, Amparo, "El permiso y la prestación por paternidad en la Ley Orgánica para la Igualdad", Revista de Trabajo y Seguridad Social. CEF, no 300, 2008, p. 71, al afirmar que "sin la participación del padre en el cuidado de los hijos no puede haber un reparto equilibrado de las responsabilidades familiares, lo que -obviamente- dificulta el acceso y, sobre todo, la permanencia de las mujeres en el mercado de trabajo". Vid. también, Molins GARCíA-ATANCE, Juan, "La reforma de las prestaciones de maternidad y paternidad por la Ley Orgánica para la igualdad efectiva de mujeres y hombres", Revista del Ministerio de Trabajo y Asuntos Sociales, $\mathrm{n}^{\circ}$ 79, 2009, p. 180; MARTíNEZ MORENO, Carolina y CASTRO ARGÜELLES, María Ángeles, "La protección social de las situaciones de maternidad y paternidad", en Moreneo Pérez, José Luís; Molina NaVARrete, Cristóbal y Moreno Vida, María Nieves (Coords.): La Seguridad Social a la luz de las reformas pasadas, presentes y futuras: homenaje al profesor José Vida Soria con motivo de su jubilación, Comares, Granada, 2008, p. 948 y 949; y LouSADA ARochena, José Fernando, Permiso de paternidad y conciliación masculina, Bomarzo, Albacete, 2008, p. 7 a 9.
} 
consideración por el empresario a la hora de tratar de un modo distinto a ambos colectivos en relación con su integración, promoción y estabilidad laboral.

Un primer y trascendental paso en esta línea de actuación se llevó a cabo con la introducción de una de las medidas más novedosas incorporadas en su momento por la Ley Orgánica 3/2007, de 22 de marzo, para la igualdad efectiva de mujeres y hombres (en adelante LOI), en concreto, de la suspensión del contrato por paternidad, con la que se pretendió avanzar en el objetivo de la corresponsabilidad de los hombres en las "responsabilidades familiares" o, en cualquier caso, en un reparto más equitativo de las mismas, no en vano, a partir de este momento éstos ya podían contribuir mejor a la crianza de sus hijos, contribuyéndose de este modo a evitar que la carrera profesional de la madre quedara cercenada por ser ella la que asumía en exclusiva o de forma muy mayoritaria las referidas "responsabilidades familiares"3. Esta finalidad quedaba recogida de un modo expreso en el artículo 44.3 de la LOI al establecer que "para contribuir a un reparto más equilibrado de las obligaciones familiares, se reconoce a los padres el derecho a un permiso y a una prestación por paternidad, en los términos previstos en la normativa laboral y de Seguridad Social”.

Con la loable finalidad de seguir avanzando, ahora ya de un modo mucho más contundente, en esta misma línea de actuación, se ha producido la aprobación del Real Decreto-Ley 6/2019, de 1 de marzo, de medidas urgentes para la garantía de la igualdad de trato y de oportunidades entre mujeres y hombres en el empleo y la ocupación (en adelante, Real Decreto-Ley 6/2019), cuyos artículos 2 y 3, en palabras de la propia Exposición de Motivos de la norma, "equiparan, en sus respectivos ámbitos de aplicación, la duración de los permisos por nacimiento de hijo o hija de ambos progenitores" . De conformidad con la misma Exposición de Motivos, esta equiparación

\footnotetext{
${ }^{3}$ Para un estudio y valoración de la implantación de la suspensión del contrato por paternidad por la LOI vid. MoReno GenÉ, Josep, "La suspensión del contrato de trabajo y la prestación por paternidad de los trabajadores por cuenta ajena diez años después de la aprobación de la Ley de Igualdad", en ROMERO Burillo, Ana María (Dira. y Coorda.) y RodríGuez Orgaz, Cristina (Coorda.): Trabajo, Género e Igualdad. Un estudio jurídico-laboral tras diez años de la aprobación de la LO 3/2007 para la igualdad efectiva de mujeres y hombres, Thomson Reuters Aranzadi, Cizur Menor (Navarra), 2018, p. 141 a 209.

${ }^{4}$ Vid. un estudio de esta norma en BALLESTER PASTOR, María Amparo, "El RDL 6/2019 para la garantía de la igualdad de trato y de oportunidades entre mujeres y hombres en el empleo y la ocupación: Dios y el Diablo en la tierra del sol", Temas Laborales, n 146, 2019; CABERO MORÁn, Enrique, "La conversión de las situaciones de maternidad y paternidad en la de nacimiento y cuidado de menor por el principio de corresponsabilidad", Trabajo y Derecho, n 53, 2019; CORDERO GORDILlo, Vanesa, "La suspensión del contrato de trabajo por nacimiento de hijo o hija, adopción, guarda con fines de adopción y acogimiento tras el RDL 6/2019, de 1 de marzo", Revista Internacional y Comparada de Relaciones Laborales y Derecho del Empleo, volumen 7, $\mathrm{n}^{\circ}$ 3, 2019; GORELLI HERNÁNDEZ, Juan, "Hacia la corresponsabilidad mediante la suspensión por nacimiento de hijos", Revista General del Derecho del Trabajo y de la Seguridad Social, n 53, 2019, p. 283; MORENO GENÉ, Josep, "De la suspensión del contrato por paternidad
} 
responde a la existencia de una voluntad y demanda social, que no puede ser desatendida y, además, se trata de una exigencia derivada de los artículos 9.2 y $14 \mathrm{CE}$, de los artículos 2 y 3.2 del Trabado de la Unión Europea y de los artículos 21 y 23 de la Carta de los Derechos Fundamentales de la Unión Europea. Por lo demás, la Exposición de Motivos de la norma también pone de manifiesto que con esta medida "se da un paso importante en la consecución de la igualdad real y efectiva entre hombres y mujeres, en la promoción de la conciliación de la vida personal y familiar, y en el principio de corresponsabilidad entre ambos progenitores, elementos ambos esenciales para el cumplimiento del principio de igualdad de trato y de oportunidades entre hombres y mujeres en todos los ámbitos".

En desarrollo de esta previsión, el vigente artículo 48.4 ET, tras contemplar la suspensión del contrato por nacimiento - parto y cuidado de menor de doce meses- que corresponde a la madre biológica, contempla la suspensión del contrato por nacimiento del otro progenitor distinto a la madre biológica, estableciéndose al respecto que en este supuesto el nacimiento suspenderá el contrato de trabajo durante 16 semanas, de las cuales serán obligatorias las seis semanas ininterrumpidas inmediatamente posteriores al parto, que habrán de disfrutarse a jornada completa, para el cumplimiento de los deberes de cuidado previstos en el artículo 68 del Código Civil.

Como ya hemos indicado, no cabe duda que la equiparación de la duración de la suspensión del contrato de trabajo de ambos progenitores constituye un paso necesario, aunque no suficiente, para evitar que las medidas de protección de la parentalidad o familia, y los efectos negativos que el mercado de trabajo les asocia, se vinculen exclusivamente o principalmente a las mujeres, al mismo tiempo que se erige como un claro factor de promoción de la conciliación de la vida personal y familiar y, sobretodo, del principio de corresponsabilidad de ambos progenitores ${ }^{5}$.

\footnotetext{
a la suspensión del contrato del otro progenitor por nacimiento de hijo ¿un paso definitivo hacia la corresponsabilidad?", Nueva Revista Española de Derecho del Trabajo, nº 227, 2020; MOLINA GonZÁLEZPUMARIEGA, Braulio, "Un paso más hacia la corresponsabilidad real: la suspensión del contrato de trabajo por nacimiento de hijo o hija, por adopción, guarda con fines de adopción y acogimiento tras el Real Decreto-Ley 6/2019", Derecho Social y Empresa, nº 12, 2020; PASTOR MARTínEZ, Albert, "Las medidas laborales del Real Decreto-Ley 6/2019, de 1 de marzo de medidas urgentes para garantía de la igualdad de trato y de oportunidades entre mujeres y hombres en el empleo y la ocupación: un paso hacia la efectividad de la igualdad de trato y oportunidades desde la corresponsabilidad", IUSlabor, n 1, 2019; PERÁN QUESADA, Salvador, "De la tutela diferenciada de la maternidad y la paternidad a la protección por nacimiento y cuidado de menor desde una perspectiva constitucional", Revista de Derecho de la Seguridad Social, $\mathrm{n}^{\circ}$ 20, 2019.

5 Vid. Pastor Martínez, Albert, "Las medidas laborales..." cit. p. 199. Vid. también, Ballester PASTOR, María Amparo, "El RDL 6/2019 para la garantía de la igualdad de trato...” cit. p. 27.
} 
Paralelamente a la equiparación de la duración de la suspensión del contrato por nacimiento de hijo que corresponde al otro progenitor con la prevista para la madre biológica, el Real Decreto-Ley 6/2019 procedió a eliminar el ya clásico permiso previsto para el supuesto de nacimiento de un hijo previsto hasta el momento en el artículo 37.3 b) $\mathrm{ET}^{6}$. A tal efecto, cabe recordar que la anterior suspensión del contrato por paternidad era independiente y, en su caso, acumulable al referido permiso por nacimiento de un hijo previsto en el referido artículo 37.3 b) ET, que recogía para estos supuestos el derecho del padre a un permiso de apenas dos días ampliable a cuatro en caso de que fuera necesario un desplazamiento.

En este punto, cabe recordar que las finalidades perseguidas por el permiso por nacimiento de un hijo y la suspensión del contrato por paternidad eran distintas, no en vano, "mientras que con la licencia retribuida de dos días por nacimiento de hijo se pretendía que el padre acompañara a la madre en el alumbramiento y en los días posteriores al mismo, en la suspensión del contrato por paternidad lo que se pretendía era alcanzar una mayor corresponsabilidad por parte del otro progenitor en el cuidado del hijo" 7 .

Esta supresión del permiso por nacimiento de hijo previsto hasta el momento en el artículo 37.3.b) ET ha planteado un interesante debate sobre la vigencia de diferentes cláusulas incorporadas a numerosos convenios colectivos que recogían y, en no pocas ocasiones, mejoraban, el referido permiso por nacimiento de hijo y, en particular, sobre si las mismas quedaban sin vigencia tras el Real Decreto-Ley 6/2019 o si, por el contrario, los trabajadores aún podían acudir a las mismas para disfrutar del permiso por nacimiento de hijo, acumulándolo a la correspondiente suspensión del contrato por nacimiento prevista a tal efecto para el otro progenitor. Precisamente, en la sentencia de 27 de enero de 2021 (núm. rec. 188/2019), objeto de este comentario, el Tribunal Supremo aborda por primera vez esta cuestión, pronunciándose al respecto en sentido contrario al criterio mantenido hasta el momento, fundamentalmente, por la Audiencia Nacional en numerosas resoluciones judiciales.

\footnotetext{
${ }^{6}$ La eliminación de este permiso por nacimiento de hijo comportó que, ateniendo a la entrada en vigor de las nuevas redacciones regulada en la Disposición Final Segunda, se haya producido un desajuste, ya que la eliminación del permiso de nacimiento que recogía el artículo 37.3.b) TRLET entró en vigor el 8 de marzo, mientras que la ampliación de la suspensión del contrato por paternidad no entró en vigor hasta el 1 de abril.

${ }^{7}$ Sobre la distinción entre la suspensión del contrato por paternidad y el permiso por nacimiento de hijo vid. Fernández Collados, María Belén, "La suspensión del contrato de trabajo por paternidad y el permiso retribuido por nacimiento de hijo: dos medidas de conciliación de la vida familiar y laboral, diferentes y compatibles", Revista Doctrinal Aranzadi Social, nº 3, 2009.
} 


\section{La admisión de la acumulación del permiso por nacimiento de hijo previsto en la negociación colectiva con la suspensión del contrato de trabajo por nacimiento de hijo introducida por el Real Decreto-Ley 6/2019: el criterio de la Audiencia Nacional y de algún Tribunal Superior de Justicia}

La Audiencia Nacional ha tenido la oportunidad de abordar en distintas ocasiones la cuestión de si los trabajadores afectados por diferentes convenios colectivos tenían derecho a disfrutar del permiso retribuido por nacimiento de hijo o hija contemplado en los referidos convenios colectivos y, en su caso, cuando podía ejercerse dicho derecho. A tal efecto, encontramos, la sentencia de 29 de noviembre de 2019 (núm. proc. 221/2019) - Convenio colectivo de la empresa Renault España, S.A.-; la sentencia de 18 de febrero de 2020 (núm. proc. 274/2019) -Convenio colectivo de Contact Center-; la sentencia de 21 de febrero de 2020 (núm. proc. 275/2019) -Convenio colectivo del Grupo de Empresas AENA-; la sentencia de 5 de marzo de 2020 (núm. proc. 278/2019) Convenio colectivo de la Compañía Logística de Hidrocarburos); y, finalmente, la sentencia de 30 de octubre de 2020 (núm. proc. 59/2020) -Convenio colectivo de Paradores Nacionales-.

En todas estas resoluciones judiciales se resuelven diferentes conflictos colectivos planteados por diferentes organizaciones sindicales en los que se reclama que se reconozca el derecho de los trabajadores y trabajadoras incluidos en el ámbito de aplicación de determinados convenios colectivos a disfrutar del permiso por nacimiento de hijo o hija previsto en dichos convenios, al considerarse que dichas previsiones no se han visto afectadas por la entrada en vigor del Real Decreto 6/2019 que, como ya hemos anticipado, ha procedido a suprimir la previsión legal del permiso por nacimiento de hijo contenida hasta su entrada en vigor en el artículo 37.3.b) ET.

En este punto, el objeto del litigio se fija en todos estos supuestos en determinar la incidencia que ha podido tener la entrada en vigor del Real Decreto-Ley 6/2019 en el permiso o licencia por nacimiento de hijos reconocidos en los respectivos convenios colectivos de aplicación, cuya duración varía en función del convenio colectivo en cuestión, pero que, en todo caso, siempre mejoraba la prevista en su momento por el artículo 37.3.b) ET -v.gr. cuatro días laborables ampliables a seis naturales en caso de desplazamiento en el artículo 30 del Convenio colectivo de la empresa Renault España S.A.; tres días naturales en el artículo 28 Convenio colectivo de Contact Center; tres días laborables ampliables por un día laborable más en caso de desplazamiento en el artículo 36 del Convenio colectivo de la empresa Compañía Logística de Hidrocarburos; diez días en el artículo 81.1 del Convenio colectivo del Grupo de AENA; y, finalmente, cinco días laborales en los artículos 20.2 y 20.3 del Convenio colectivo de Paradores de Turismo de España-. 
A tal efecto, la Audiencia Nacional recuerda en todos los supuestos en que ha tenido que enfrentarse a esta cuestión litigiosa que los artículos 2 y 3 del Real Decreto-Ley 6/2019 equiparan en sus respectivos ámbitos de aplicación la duración de los permisos por nacimiento de hijo o hija de ambos progenitores. Con ello, a criterio del Tribunal, se da un paso importante en la consecución de la igualdad real y efectiva entre hombres y mujeres, en la promoción de la conciliación de la vida personal y familiar, y en el principio de corresponsabilidad entre ambos progenitores, elementos esenciales para el cumplimiento del principio de igualdad de trato y de oportunidades entre hombres y mujeres en todos los ámbitos.

Constata asimismo la Audiencia Nacional que esta previsión ha venido acompañada de la supresión por parte del Real Decreto-Ley 6/2019 del anterior permiso previsto en el artículo 37.3.b) ET de dos días por nacimiento de hijo ampliable en caso de desplazamiento a cuatro días.

En definitiva, la Audiencia Nacional pone de manifiesto que el Real Decreto-Ley 6/2019 ha comportado dos modificaciones por lo que respecta al objeto del litigio: a) la desaparición del permiso legal por nacimiento de hijo; y, b) la ampliación de los períodos de suspensión del contrato de trabajo por paternidad del trabajador, ahora denominado por nacimiento de hijo, equiparándose para ambos progenitores a dieciséis semanas.

A partir de estas premisas, el Tribunal aborda la cuestión de determinar si una vez eliminado del Estatuto de los Trabajadores el permiso por nacimiento de hijo, se debe conceder o no al trabajador dicho permiso si el convenio colectivo lo contempla.

En este punto, la Audiencia Nacional recuerda en sus sentencias de 29 de noviembre de 2019 (núm. proc. 221/2019), de 21 de febrero (núm. proc. 275/2019), de 5 de marzo (núm. proc. 278/2019) y de 30 de octubre de 2020 (núm. proc. 93/2020) que los convenios colectivos en cuestión son anteriores a la entrada en vigor del Real Decreto-Ley 6/2019 y la consiguiente modificación del artículo 37.3 b) ET que dicha norma conlleva. Dichos convenios se integran, a criterio del Tribunal, en el sistema de fuentes laborales y más en concreto en el artículo 3.1.b) ET, lo que comporta que a la situación de concurrencia generada en esta materia le serán de aplicación las reglas de solución de concurrencia previstas en el artículo 3 ET, a saber: los principios de jerarquía y modernidad; la prevalencia de las normas de Derecho necesario absoluto, el principio de norma más favorable y la preferencia aplicativa de los "mínimos de Derecho necesario".

En particular, la Audiencia Nacional considera de aplicación al caso el artículo 3.3. ET, según el cual los conflictos originados entre los preceptos de dos o más normas laborales, tanto estatales como pactadas, que deberán respetar en todo caso los mínimos de derecho 
necesario, se resolverán mediante la aplicación de lo más favorable para el trabajador apreciado en su conjunto, y en cómputo anual, respecto de los conceptos cuantificables.

A tal efecto, considera el Tribunal que en el supuesto enjuiciado nos hallamos ante normas legales que fijan condiciones mínimas, de modo que la ley, sin intención de plenitud o monopolio, se limita a fijar unas condiciones "mínimas", que en cuanto a tales son también imperativas, pero que, precisamente en cuanto mínimas, dejan abierta la posibilidad de ser elevadas o mejoradas por otras normas, básicamente por lo convenios colectivos.

A tal efecto, la disposición derogatoria única del Real Decreto-Ley 6/2019 se limita a derogar las normas de igual o inferior rango que se opongan o contradigan a lo dispuesto en dicha norma, pero no establece de forma expresa la derogación de las normas convencionales que mejoren o superen lo dispuesto en el Estatuto de los Trabajadores, sin que pueda desconocerse que "las normas convencionales pueden complementar o mejorar los derechos básicos regulados en el ET, cuya modificación o reforma, en tanto en cuanto no desborde o contradiga los derechos mejorados deben mantenerse subsistentes los que sean beneficiosos de conformidad con lo ya negociado, atendiendo al principio de favorabilidad de sus efectos positivos, al margen de la prioridad y preferencia aplicativa jerárquica porque no nos hallamos ante un supuesto de derecho necesario establecido por la ley, que, en razón de la superior posición que ocupa en la jerarquía normativa, puede desplegar una virtualidad limitadora de la negociación colectiva".

Por tanto, a criterio de las ya citadas sentencias de la Audiencia Nacional de 29 de noviembre de 2019 (núm. proc. 221/2019), de 21 de febrero (núm. proc. 275/2019), de 5 de marzo (núm. proc. 278/2019) y de 30 de octubre de 2020 (núm. proc. 93/2020), la supresión por la ley de la regulación del permiso por nacimiento de hijo, no supone que el derecho quede automáticamente eliminado del régimen jurídico aplicable a los trabajadores, en la medida en que continúa previsto en el convenio colectivo, que mantiene su carácter de fuente del derecho reguladora de los derechos y obligaciones concernientes a la relación laboral de conformidad con lo establecido en el artículo 3.1.b) ET, en tanto que la nueva norma legal no genera ningún tipo de contradicción con la regulación convencional. Por tanto, el permiso por nacimiento de hijo, desaparece el respaldo de mínimos de rango legal, pasando a regirse exclusivamente y de manera autónoma por lo dispuesto en el convenio colectivo y, en su caso, por las mejoras que pueden pactarse mediante acuerdo con el empresario.

Por lo demás, con cita de la jurisprudencia del Tribunal Supremo y del Tribunal Constitucional, la Audiencia Nacional apunta que ante la dimensión constitucional de los 
derechos de conciliación de la vida familiar y laboral en la que se incardina la materia objeto de este litigio, la normativa aplicable debe aplicarse siempre del modo más favorable al efectivo ejercicio de los mismos, neutralizando así también una posible discriminación indirecta por razón de sexo.

Precisamente, en aplicación de esta doctrina, la SAN de 21 de febrero de 2020 (núm. proc. 275/2019) considera que "no puede considerarse que la entrada en vigor del RD Ley 6/2019 implique la derogación de los permisos y licencias previstos en los Convenios colectivos que mejorasen el desaparecido permiso retribuido por nacimiento que se recogía en la anterior redacción del artículo 37.2 b) ET, máxime en supuestos como el presente en que la existencia de la mejora no se vincula directamente por las partes negociadoras a la previa existencia de un derecho similar reconocido en el marco legal general el cual se mejora".

A mayor abundamiento, la Audiencia Nacional recuerda, en su sentencia de 29 de noviembre de 2019 (núm. proc. 221/2019), que la suspensión del contrato por paternidad que los trabajadores incluidos en el ámbito de aplicación del convenio venían disfrutando hasta el momento, era compatible con el permiso por nacimiento de hijos establecido en el convenio y, por tanto, "la novedad legislativa no puede enervar este permiso con base a lo dispuesto en el (...) convenio". Además, el Tribunal precisa que "nos encontramos ante derechos de distinta naturaleza, ya que uno es a disfrutar de un permiso retribuido a cargo del empresario y otro, bien distinto, que es una suspensión del contrato de trabajo, sin obligación retributiva para el empresario y, en cambio, con cobertura prestacional por el sistema público de seguridad social si se cumplen los requisitos para ser beneficiario del mismo; por ello, ambos derechos se han de disfrutar plenamente sin que pueda ser suprimido el contemplado en el convenio, cuya finalidad sigue estando plenamente vigente, sin que nada impida que su disfrute se lleve a cabo una vez finalizado el periodo de suspensión del contrato si se tiene en cuenta que el convenio no concreta la fecha de su disfrute y ello aunque se haya incrementado el periodo de suspensión del contrato de trabajo del progenitor distinto de la madre biológica (...) todo ello sin perjuicio de la modificación del régimen convencional a que pueden llegar las partes en la negociación colectiva que atienda a una restructuración de este permiso".

En definitiva, a criterio de la Audiencia Nacional "ya se entienda el cómputo del permiso discutido desde la fecha del hecho causante o desde el consumo del periodo de suspensión del contrato, lo evidente es que los negociadores quisieron el disfrute añadido a ambos beneficios previstos en el Estatuto de los Trabajadores en la fecha en que se suscribió el convenio que ya contemplaba la suspensión del contrato de trabajo por paternidad, si bien por un periodo de tiempo inferior al establecido en el Real Decreto-Ley 6/2019 y, sin que ni la regulación convencional ni la que contiene la norma estatutaria, tras la 
reforma dada por dicho real decreto ley ampare la absorción y compensación invocada por la parte demandada".

Además, la SAN de 5 de marzo de 2020, (núm. proc. 278/2019) añade que esta solución adoptada no supone un "espigueo normativo", tal como denuncia la empresa, "toda vez que la suspensión del contrato por nacimiento de hijo y el permiso retribuido por tal circunstancia son medidas de conciliación de naturaleza diferentes, pues si bien en la primera con arreglo al artículo 45.2 ET desaparecen las obligaciones de trabajar y retribuir y se genera una prestación de seguridad social sustitutiva del salario, en el segundo el contrato de trabajo sigue en vigor, si bien se dispensa al trabajador por el hecho causante de prestar servicios por un número determinado de días".

Otro de los argumentos esgrimidos por las empresas para justificar la eliminación del permiso por nacimiento de hijo en estos supuestos se apoya en que, de conformidad con la redacción dada al mismo por diferentes convenios colectivos, su disfrute sería imposible, ya que el mismo debería disfrutarse en los días inmediatamente posteriores a la fecha del nacimiento, fechas en las que, tras la entrada en vigor del Real Decreto-Ley $6 / 2019$, el contrato de trabajo del otro progenitor se encontraría en suspenso precisamente por el nacimiento del hijo.

Esta cuestión se aborda específicamente por la SAN de 21 de febrero de 2020 (núm. proc. 275/2019) que al interpretar el artículo 81.1 del Convenio colectivo del Grupo de Empresas AENA considera que existen dos interpretaciones posibles al respecto: a) la invocada por la empresa, según la cual el primer día del disfrute del permiso por nacimiento de hijo coincidiría con la de inicio del hecho causante con independencia de que en el mismo exista o no una obligación efectiva de prestar servicios; y b) la invocada por la representación de los trabajadores, que considera que el término "derecho a ausentarse" implica que exista una obligación efectiva de presencia el día de inicio del permiso, lo que implica que el dies a quo de inicio del permiso ha de ser aquel posterior a la fecha de inicio hecho causante en el que exista una previa obligación de prestar servicios.

En este contexto, la SAN de 21 de febrero de 2020 (núm. proc. 275/2019) aboga por una interpretación finalista del precepto convencional, en virtud de la cual, resulta patente que al fijarse el permiso por nacimiento de hijo, la voluntad de las partes negociadoras fue que las empresas asumieran por un periodo de diez días naturales el abono de las retribuciones salariales de los trabajadores sin que estos se viesen obligados a prestar servicios durante este periodo de tiempo para que pudieran atender debidamente las obligaciones que en su condición de progenitor le impone la normativa civil, en un 
momento especialmente sensible para la vida del menor cual es el de su nacimiento, adopción o acogimiento.

A lo cual, se añade por la Audiencia Nacional, que "el concepto de nacimiento en el actual marco legislativo no se circunscribe al momento del parto o alumbramiento, sino que se extiende durante los doce primeros meses de vida del menor a tenor de lo dispuesto en el artículo 48.4 ET, lo que hace que la situación especial de necesidad de cuidado del menor causante del permiso subsista aun habiendo expirado el periodo de suspensión del contrato de trabajo". Por ello, a criterio del Tribunal, la finalidad del permiso por nacimiento subsiste aún después del periodo de suspensión del contrato.

En esta misma dirección, la SAN de 5 de marzo de 2020 (núm. proc. 278/2019) concluye, al interpretar el artículo 84.1 del Convenio colectivo de la Compañía Logística de Hidrocarburos, que en el supuesto enjuiciado cabe concluir que "el hecho causante del permiso - en este caso, el nacimiento- tal y como aparece regulado en la actualidad legalmente, sigue manifestándose a la fecha de la conclusión de la suspensión del contrato por dicha causa" y la SAN de 30 de octubre de 2020 (núm. proc. 93/2020) establece que "la aplicación de los anteriores criterios al precepto cuya interpretación se discute no deja lugar a dudas respecto de los mandatos que contiene y, tampoco, de la intención de los contratantes. En efecto, el contrato quiso supeditar el disfrute de los permisos y licencias al cumplimiento de los fines que los motivan".

Finalmente, también se alega en alguna ocasión por las empresas afectadas que al reconocerse el permiso de nacimiento de hijo exclusivamente a los padres, la concesión a los mismos de este derecho, sumado a la suspensión del contrato de trabajo por nacimiento de hijo que también se reconoce a los mismos, supondría una discriminación hacia las mujeres, que únicamente disfrutarían de la suspensión del contrato de trabajo por nacimiento de hijo.

Esta cuestión también ha sido abordada específicamente por la SAN de 21 de febrero de 2020 (núm. proc. 275/2019), que al interpretar el artículo 81.1.d) del Convenio colectivo del Grupo de Empresas AENA considera que dicho precepto, al reconocer el permiso por nacimiento de hijo no distingue entre trabajadores de un sexo o de otro, "por lo que el permiso, con arreglo a lo que se acaba de razonar, podrá ser disfrutado tanto por hombres, como por madres no biológicas como por madres biológicas, y lo que efectivamente supondría una discriminación directa de sexo con arreglo al artículo 8 de la LO 3/2007 sería la hipotética denegación del mismo por el hecho de ser madre biológica". 
Finalmente, un caso peculiar sobre esta materia es el abordado por la SAN de 18 de febrero de 2020 (núm. proc. 274/2019), por cuanto que, a pesar de que en el conflicto colectivo se solicitaba que se declarara el derecho de los trabajadores afectados por el Convenio colectivo de Contact Center a disfrutar del permiso retribuido por nacimiento de hijo o hija contemplado en dicho convenio colectivo, así como que también se fijara el periodo de disfrute del mismo tras la finalización de la suspensión contractual por nacimiento, la empresa demandada alega falta de acción, puesto que la misma no se había opuesto en ningún momento al reconocimiento del permiso a los trabajadores que lo soliciten, admitiendo sin ambages la plena validez del mismo, sin perjuicio de su voluntad de proponer su eliminación en la negociación del futuro convenio colectivo.

Ante esta situación, la Audiencia Nacional recuerda la consolidada doctrina que exige que la acción venga justificada por la existencia de una verdadera controversia, sin que se puedan plantear "cuestiones no actuales ni efectivas, futuras o hipotéticas, o cuya decisión no tenga incidencia alguna en la esfera de derechos e intereses del actor; se requiere que exista una un caso o controversia, una verdadera litis, pero no cabe solicitar al juez una mera opinión o un consejo". Por todo ello, en el supuesto enjuiciado se desestima la demanda por falta de acción.

Esta problemática también ha sido abordada y resuelta en los mismos términos por algún Tribunal Superior de Justicia, como es el caso, del Tribunal Superior de Justicia de Cantabria ${ }^{8}$.

El origen del conflicto colectivo abordado en este supuesto es la supresión del permiso por nacimiento de hijo al considerar la empresa que la entrada en vigor del Real Decreto Ley 6/2019 suponía la absorción del permiso por nacimiento de hijo que existía en el convenio colectivo estatal de industrias lácteas y sus derivados. Asimismo, la empresa adujo que, de mantenerse este permiso por nacimiento de hijo, el progenitor tendría más permiso que la madre biológica, lo que "llevaría a una interpretación discriminatoria contraria a la previsión del RD 6/2019".

La representación sindical se opuso a este comportamiento empresarial alegando que se deben "respetar los convenios y pactos colectivos los mínimos de derecho necesarios en sus normas más favorables", en este caso los cuatro días de permiso por nacimiento de hijo que están contenidos en el pacto de aplicación de la empresa Lácteos de Santander. Para ello, el sindicato solicitó que estas jornadas fuesen disfrutadas inmediatamente después que finalizara el periodo de suspensión de contrato de trabajo por nacimiento de dieciséis semanas, al no concretar la fecha de disfrute.

8 Vid. https://www.20minutos.es/noticia/4529996/0/los-antiguos-permisos-de-paternidad-podrananadirse-a-las-16-semanas-por-nacimiento-segun-tsjc/?autoref=true 
Para el Tribunal Superior de Justicia de Cantabria, el "efecto" de la supresión del permiso retribuido de paternidad por nacimiento de hijo "no implica la derogación de los permisos y licencias previstos en los convenios colectivos que lo mejorasen". A tal efecto, se indica que "los conflictos originados entre los preceptos de dos o más normas laborales, tanto estatales como pactadas, deberán respetar en todo caso los mínimos necesarios y se resolverán mediante la aplicación de lo más favorable para el trabajador apreciado en su conjunto y en cómputo anual".

La sentencia concluye por ello que "suprimida por ley la regulación del permiso por nacimiento de hijo, el derecho no queda automáticamente eliminado del régimen jurídico aplicable a los trabajadores en la medida en que continúa previsto en el pacto y convenio colectivo". El tribunal cántabro indica además que ambos permisos de paternidad y nacimiento son "de naturaleza diferente", ya que uno supone una suspensión del contrato de trabajo, con coste a cargo de la Seguridad Social, y el otro supone una dispensa de prestar servicios con cargo al empresario.

Por ello, el Tribunal Superior de Justicia de Cantabria acaba dictaminando que, una vez finalizado el permiso de nacimiento de dieciséis semanas, deberá ser disfrutado el permiso de nacimiento de hijo, que en el caso de Lácteos de Santander es de cuatro días.

\section{La incompatibilidad del permiso por nacimiento de hijo previsto en la negociación colectiva con la suspensión del contrato de trabajo por nacimiento de hijo tras el Real Decreto-Ley 6/2019: el criterio del Tribunal Supremo}

Frente a esta más que consolidada doctrina de la Audiencia Nacional, se alza ahora el Tribunal Supremo en su sentencia de 27 de enero de 2021 (núm. rec. 188/2019), al conocer de un recurso de casación interpuesto contra la Stsj del País Vasco de 16 de julio de 2019 (núm. proc. 16/2019), que había desestimado un conflicto colectivo en el que se solicitaba que se reconociera el derecho de los trabajadores de la empresa Eusko Trenbideak-Ferrocarriles Vascos, SAU, a disfrutar de los tres días de permiso por paternidad previstos en el artículo 30 del Convenio colectivo de la empresa -Convenio colectivo de la Sociedad Pública Eusko Trendibeak/Ferrocarriles Vascos, S.A.-, frente al criterio de la empresa que negaba que dicho precepto estuviera vigente tras la entrada en vigor del Real Decreto-Ley 6/2019.

El razonamiento jurídico contenido en la STSJ del País Vasco de 16 de julio de 2019 (núm. proc. 16/2019), como no podía ser de otro modo, parte de la constatación, una vez más, de que el Real Decreto-Ley 6/1019 ha introducido dos novedades que afectan a la cuestión litigiosa: por una parte, la eliminación del permiso de dos días por nacimiento de hijo que, hasta el momento, establecía el artículo 37.3 b) ET; y, por otra parte, la 
introducción en el artículo 48.4 de una nueva regulación de la suspensión del contrato por nacimiento del otro progenitor distinto a la madre biológica de dieciséis semanas, de las cuales serán obligatorias las seis semanas ininterrumpidas inmediatamente posteriores al parto. En consecuencia, tras la entrada en vigor de esta norma, a criterio del Tribunal, se produce la desaparición del permiso legal por paternidad, que el artículo 30 del Convenio colectivo aplicable mejoraba para los trabajadores y la implantación de un nuevo régimen que desborda el sentido y utilidad del citado artículo 30 del Convenio.

A partir de esta premisa, el TSJ del País Vasco considera que debe desestimar la petición de que se reconozca a los trabajadores el derecho a disfrutar de los tres días de permiso de paternidad previstos en el artículo 30 del convenio, en tanto que "no puede aceptarse la vigencia en el convenio de la mejora de un derecho legal que ya no existe; ni resulta legítimo, en relación a idéntica materia y derecho, que los trabajadores pretendan acogerse a dos fuentes distintas (el convenio y la ley)".

A tal efecto, el Tribunal vasco mantiene que tanto el permiso por nacimiento de hijo reconocido en el convenio como la suspensión del contrato por dicha causa previsto en la ley deben ser efectivos a partir de la fecha del alumbramiento, por lo que la pretensión de la parte actora implicaría un solapamiento o coincidencia cronológica entre los tres días de permiso y los tres primeros días de las semanas de suspensión del contrato, sin que, además, el artículo 30 del convenio admita el uso del permiso en un momento posterior, que sería al finalizar la suspensión, ni la regulación legal de esta última admite la demora de su inicio por razón de previsiones pactadas colectivamente en convenio colectivo.

Dicha sentencia, sin embargo, cuenta con un voto particular formulado por el magistrado Juan Carlos Benito Butron Ochoa, en el que se constata la finalidad del precepto convencional ahora cuestionado - artículo 30-, entendiéndose al respecto que "existe una voluntad manifiesta y negociada de establecer un permiso de tres días naturales añadido, complementando o mejorando al permiso legalmente establecido que concernía a una duración de disfrute como descanso según la legislación vigente en cada momento". A ello cabe añadir, según el magistrado, que el Real Decreto 6/2019 no establece de forma expresa ningún tipo de derogación de las normas convencionales que mejoren o superen la consecución de los derechos tratados.

A partir de estas premisas, el magistrado concluye que "entendamos el cómputo o devengo del permiso discutido, desde la fecha en que se produzca el parto, o desde el consumo del permiso legalmente establecido, lo evidente es que los negociadores quisieron el disfrute añadido de ambos beneficios, al redactar en la literalidad del artículo 30 de aquella forma "además del permiso establecido". 
No siendo, sin embargo, el criterio del voto particular el mayoritario, como ya se ha avanzado, la STSJ del País Vasco de 16 de julio de 2019 (núm. proc. 16/2019) desestima la demanda y, en consecuencia, deniega el derecho de los trabajadores afectados por el Convenio colectivo a disfrutar de los tres días de permiso por paternidad previstos en el artículo 30 de dicho convenio.

Disconformes con esta decisión, diferentes organizaciones sindicales plantean el correspondiente recurso de casación que es finalmente resuelto por la STS de 27 de enero de 2021 (núm. rec. 188/2019), objeto de este comentario.

Para abordar esta cuestión, el Tribunal Supremo lleva a cabo una exégesis exhaustiva de la evolución normativa que han tenido tanto el permiso por nacimiento de hijo como la suspensión del contrato por maternidad y paternidad, hasta llegar a la regulación actual establecida por el Real Decreto-Ley 6/2019.

A partir de esta exégesis normativa el Alto Tribunal llega a la conclusión de que la supresión del permiso retribuido de dos días por nacimiento de hijo que reconocía el artículo 37.3 b) ET, unida a la equiparación de la duración de la suspensión del contrato de trabajo de ambos progenitores, hacen inaplicable el precepto del convenio colectivo de empresa que mejoraba la previsión legal sobre aquel permiso, invocándose al respecto dos motivos principales.

En primer lugar, porque el artículo 30 del convenio colectivo al contener la expresión de "además del permiso legalmente establecido", hace referencia a un permiso que ya no existe. A tal efecto, la supresión de dicho permiso se debe a la equiparación de la duración de la suspensión del contrato de trabajo por causa de nacimiento de ambos progenitores. En consecuencia, a criterio del Alto Tribunal, el artículo 30 del convenio colectivo mejora un permiso que tras el Real Decreto-Ley 6/2019 ha dejado de existir. En este punto, considera el Tribunal Supremo que la previsión del artículo 30 del convenio se vincula tanto al anterior permiso legal de dos días del artículo 37.3 b) ET, que es difícil pensar que pueda tener vida autónoma propia una vez que dicho permiso legal ha dejado de existir sin haber sido sustituido por ningún otro.

En segundo lugar, y más importante, porque el artículo 30 del convenio colectivo establece como momento temporal de ejercicio del permiso retribuido de tres días por nacimiento de hijo "desde la fecha en que se produzca el parto", lo cual, a criterio del Tribunal, no es compatible ni puede conciliarse con las previsiones sobre el comienzo de la suspensión del contrato por nacimiento. A tal efecto, el artículo 48.4 ET establece que, de las dieciséis semanas de descanso, son obligatorias las seis semanas inmediatamente posteriores al parto, de lo que el Alto Tribunal deduce que "no hay espacio temporal para 
que se haya podido disfrutar previamente del anterior permiso retribuido de dos días por nacimiento".

Por si ello fuera poco, el Tribunal Supremo mantiene, en relación con la posibilidad de que el permiso por nacimiento de hijo pueda disfrutarse con posterioridad a la suspensión del contrato por causa de nacimiento, que "las reglas de interpretación de los convenios colectivos, que son tanto las de las leyes como las de los contratos (...) llevan a descartar que tenga sentido un permiso retribuido de tres días por nacimiento, tan alejado de dicho nacimiento". Como refuerzo de esta argumentación, el Alto Tribunal recuerda que desde el mismo momento en que se creó la suspensión del contrato por paternidad, se estableció que la misma comenzaba desde la finalización del permiso por nacimiento de hijo, previsto legal o convencionalmente, es decir, "el permiso retribuido era primero y la suspensión del contrato venía después y no al contrario".

Por todo lo expuesto, el Tribunal Supremo desestima el recurso de casación y, por tanto, de conformidad con la sentencia dictada en su momento en instancia, deniega el derecho de los trabajadores afectados por el Convenio colectivo a disfrutar de los tres días de permiso por paternidad previstos en el artículo 30 de dicho convenio.

\section{La subsunción del permiso por nacimiento de hijo en la suspensión del contrato por nacimiento y sus efectos: ¿Zanja el Tribunal Supremo la cuestión?}

Como ya se ha indicado, con anterioridad a la aprobación del Real Decreto-Ley 6/2019, la más que modesta suspensión del contrato por paternidad contemplado en aquel momento en el artículo 48.7 ET era independiente y, en su caso, acumulable al permiso previsto para el supuesto de nacimiento de un hijo en el artículo 37.3 b) ET, que recogía para estos supuestos el derecho del padre a un permiso de apenas dos días ampliable a cuatro en caso de que sea necesario un desplazamiento ${ }^{9}$. A tal efecto, tras la entrada en vigor de la LOI, la STS de 19 de mayo de 2009 (núm. rec. 97/2008) había constatado de forma expresa que "junto al permiso de paternidad por tiempo breve (...) instaura la Ley de Igualdad un supuesto de suspensión del contrato de trabajo por paternidad"10.

\footnotetext{
${ }^{9}$ Vid. Pedrajas Moreno, Abdón y SAla Franco, Tomás, La protección de la maternidad, la paternidad y la adopción y acogimiento, Tirant lo Blanch, Valencia, 2008, p. 112. Vid. también, CORDERO GORDILLO, Vanesa, "La suspensión del contrato..." cit. p. 15, que relaciona el carácter modesto de la inicial suspensión del contrato de trabajo con su compatibilidad con el permiso por nacimiento de hijo del artículo 37.3 b) ET. ${ }^{10}$ A mayor abundamiento, el Tribunal Supremo considera que "esta suspensión, como se deduce de su normativa, es compatible con el permiso de paternidad de dos días ex artículo 37.3.b ET e incluso su disfrute (durante trece días ininterrumpidos, como regla) puede iniciarse tras la finalización del permiso por nacimiento de hijo, por lo que, con una y otra modalidad de permiso y suspensión, pueden disfrutarse por los trabajadores, como regla, de quince días de ausencia al trabajo con causa de la paternidad".
} 
Las finalidades perseguidas por el permiso por nacimiento de un hijo y la suspensión del contrato por paternidad eran distintas, no en vano, mientras que con la licencia retribuida de dos días por nacimiento de hijo se pretendía que el padre acompañara a la madre en el alumbramiento y en los días posteriores al mismo, en la suspensión del contrato por paternidad lo que se pretendía era la corresponsabilidad por parte del otro progenitor en el cuidado del hijo ${ }^{11}$.

Ello justifica que el disfrute del referido permiso de nacimiento se hubiera fijado, tradicionalmente, de forma inmediata al nacimiento. A tal efecto, el Tribunal Supremo, en su sentencia de 17 de enero de 2008 (núm. rec. 24/2007), relativa a los permisos por nacimiento de hijo y fallecimiento de familiares, indica que "es totalmente lógico estimar que el disfrute de estos permisos tiene que hacerse efectivo en el tiempo inmediatamente siguiente a aquél en que tuvo lugar el correspondiente nacimiento o fallecimiento (...). La razón de ser de estos permisos se debe a la gran importancia, muy especial significado y enorme carga de sentimientos y emociones que los referidos acontecimientos tienen para toda persona; de ahí que el disfrute de los mismos tenga que ser hecho efectivo en el momento en que tales sucesos acontecen, es decir, en el día en que se produjeron y en los inmediatos siguientes". A lo que el Alto Tribunal añade que "para que una licencia que se ha creado y constituido como licencia por nacimiento de hijo o fallecimiento de familiar, pueda ser disfrutada en fechas posteriores a ese alumbramiento o a esa muerte, es de todo punto obligado que la norma que la estableció disponga expresa y claramente la posibilidad de ese disfrute tardio de la misma. Si tal norma no dice nada a tal respecto, no puede admitirse ni tener por válido este cumplimiento retrasado del permiso, pues es contrario, como se vio, a la verdadera naturaleza del mismo"12.

En todo caso, la suspensión del contrato por paternidad ya prevista con anterioridad al Real Decreto-Ley 6/2019 iba más allá del referido permiso por nacimiento de hijo del artículo 37.3 b) ET, puesto que a diferencia de este permiso que sólo aludía a la paternidad biológica o natural, la suspensión del contrato por paternidad abarcaba tanto a esta paternidad biológica o natural como a los supuestos de adopción, guarda o acogimiento ${ }^{13}$.

\footnotetext{
${ }^{11}$ Vid. Fernández Collados, María Belén, "La suspensión del contrato...” cit.

12 A mayor abundamiento, el Tribunal Supremo considera que "puede ser que un determinado convenio o pacto colectivo establezca unas licencias por nacimiento de hijo o fallecimiento de familiar, y sin embargo permita el disfrute de las mismas después de haber transcurrido un cierto tiempo después de que tales sucesos hayan tenido lugar. Pero en tal caso, es evidente que se produce una clara desnaturalización de las licencias por nacimiento o defunción, pues las establecidas de esta forma en realidad no responden a las causas propias de esta clase específica de permisos, sino a otras diferentes aunque puedan tener vinculación o conexión con aquéllas".

13 En este punto, Alameda CASTilla, María Teresa, "Otro lento avance normativo hacia la corresponsabilidad familiar: suspensión del contrato de trabajo y prestación de paternidad”, en Comentarios Laborales a la Ley de Igualdad entre Mujeres y Hombres, Tirant lo Blanch, Valencia, 2007, p. 509, criticaba
} 
En todo caso, no faltaban convenios colectivos que extendían el permiso por nacimiento de hijo del artículo 37.3 b) ET también a estas otras situaciones, mejorando al respeto lo previsto en la ley ${ }^{14}$.

La tradicional compatibilidad entre el permiso por nacimiento de hijo y la suspensión del contrato por paternidad comportó incluso una cierta confusión entre ambas instituciones, de modo que, a pesar de que la regulación inicial de la suspensión del contrato por paternidad introducida por la LOI preveía con total claridad que "el trabajador tendrá derecho a la suspensión del contrato durante trece días ininterrumpidos, ampliables en el supuesto de parto, adopción o acogimiento múltiples en dos días más por cada hijo a partir del segundo", el hecho de que estos trece días fueran acumulables al permiso retribuido de dos días -ampliables a cuatro en caso de ser necesario un desplazamientopor nacimiento de hijo previsto entonces en el artículo 37.3 b) ET, llevó a que se extendiera la idea de que la suspensión del contrato por paternidad era de quince días, que resultaban de la suma de los dos días de permiso retribuido por nacimiento de un hijo de los que con carácter general se disfrutaba, más los trece días de suspensión del contrato por paternidad introducidos en aquel momento por la $\mathrm{LOI}^{15}$.

Esta compatibilidad entre el permiso por nacimiento de hijo y el descanso por paternidad se había extendido por los tribunales no únicamente al supuesto genérico previsto por la ley, sino que también amparaba a los supuestos en que el permiso por nacimiento de hijo se preveía en un convenio colectivo con anterioridad a la irrupción inicial de la suspensión del contrato por paternidad, al afirmarse que "esa compatibilidad que el artículo 48 bis del ET prevé entre el permiso por nacimiento de hijo y por razón de paternidad es clave para la resolución de la cuestión ahora debatida y ha de llevarnos a concluir idéntica compatibilidad entre la suspensión y el permiso que, por nacimiento, se recoge en el Convenio aplicable, de diez días naturales, que no prevé restricción alguna para el caso de que, en el futuro, se dispusiera un período de suspensión del contrato de trabajo"16. En esta misma dirección, la STSJ de Madrid de 21 de julio de 2011 (núm. rec. 3239/2011) establece que "se acepta sin duda alguna que ambas instituciones son compatibles, pues así se desprende claramente del artículo 48 bis párrafo tercero del ET al establecer que la suspensión podrá iniciarse "desde la finalización del permiso por nacimiento de hijo,

que este permiso retribuido se limitara a la paternidad biológica, puesto que ello suponía una minoración del período destinado al cuidado de un hijo tras su adopción o acogimiento. Vid. también una visión crítica en PÉrez CASTILlo, Ana María, "La prestación por paternidad en los casos de paternidad biológica, adopción y acogimiento. Análisis crítico", Revista del Ministerio de Trabajo y Asuntos Sociales, $\mathrm{n}^{\circ}$ Extra 3, 2007, p. 187.

${ }^{14}$ Vid. FeRnÁndez Collados, María Belén, "La suspensión del contrato...." cit.

${ }^{15}$ Sobre esta confusión tan habitual vid. Fernández Collados, María Belén, "La suspensión del contrato..." cit.

${ }^{16}$ Vid. STSJ del País Vasco de 11 de noviembre de 2008 (núm. rec. 2038/2008). 
previsto legal o convencionalmente", y tampoco es dudoso que se trata de figuras de distinta naturaleza jurídica, un permiso retribuido y una suspensión del contrato de trabajo con derecho a prestaciones de Seguridad Social. Por tanto, en principio sería posible que un convenio colectivo mejorase el permiso de dos días del artículo 37.3.b) del ET y en ese caso el trabajador tendría derecho a ese permiso aumentado por convenio y posteriormente a la prestación por paternidad".

De forma coherente con todo lo expuesto, al regularse el momento de disfrute de la suspensión del contrato por paternidad, el entonces vigente artículo 48.7 ET establecía que "el trabajador que ejerza este derecho podrá hacerlo durante el período comprendido desde la finalización del permiso por nacimiento de hijo, previsto legal o convencionalmente". En consecuencia, en estos supuestos el descanso por paternidad se disfrutaba tras finalizar el permiso por nacimiento de hijo recogido en el artículo $37.3 \mathrm{~b}$ ) $E^{17}$. Además, si la negociación colectiva establecía duraciones superiores del permiso por nacimiento de hijo, lo cual sucedía con cierta frecuencia ${ }^{18}$, el inicio de la suspensión del contrato por paternidad se iniciaba al concluir el permiso establecido en el convenio colectivo de aplicación, cualquiera que fuera su duración ${ }^{19}$.

Esta situación, sin embargo, ha cambiado sustancialmente con la entrada en vigor del Real Decreto-Ley 6/2019 que, como ya se ha anticipado, ha venido a equiparar la duración de la suspensión del contrato de trabajo para ambos progenitores. A tal efecto, una vez ha finalizado el 1 de enero de 2021 el período transitorio introducido en la disposición transitoria decimotercera ET por el Real Decreto-Ley 6/2019, de las dieciséis semanas de descanso por nacimiento que corresponden al otro progenitor, el mismo deberá disfrutar obligatoriamente de seis semanas ininterrumpidas inmediatamente posteriores al parto, que además habrán de disfrutarse a jornada completa. Son diversas las notas que definen, por tanto, este descanso: es obligatorio, de seis semanas, inmediatamente posterior al parto, ininterrumpido y a jornada completa.

A diferencia de lo que sucede respecto descanso previsto para el caso de la madre biológica, cuya finalidad es la de asegurar la protección de su salud, en el caso del otro progenitor estas características del descanso responden a la finalidad de que el mismo pueda dar cumplimiento a los deberes de cuidado que se derivan del artículo 68 del

\footnotetext{
${ }^{17}$ En esta dirección, PÉREZ CASTILlO, Ana María, “La prestación por paternidad...” cit. p. 186 y 187, indica que "con la LOIMH, el permiso reconocido en el Estatuto de los Trabajadores se convierte en un primer escalón de un nuevo período en el que el contrato de trabajo se suspende".

${ }^{18}$ Vid. Sobre estas prácticas, PÉREZ CASTILlo, Ana María, "La prestación por paternidad..." cit. p. 186 y 187.

${ }^{19}$ Vid. STSJ del País Vasco de 23 de septiembre (núm. rec. 1780/2008) y 11 de noviembre de 2008 (núm. rec. 2038/2008).
} 
Código Civil, ya sea hacia el recién nacido, pero también respecto a la madre biológica, en el supuesto que se trate de cónyuges. A tal efecto, dicho precepto establece que "los cónyuges están obligados a vivir juntos, guardarse fidelidad y socorrerse mutuamente. Deberán, además, compartir las responsabilidades domésticas y el cuidado y atención de ascendientes y descendientes y otras personas dependientes a su cargo"20.

Una vez transcurridas estas seis semanas de disfrute obligatorio, el disfrute del resto del periodo de descanso para el cuidado del menor que corresponde al otro progenitor en los supuestos de nacimiento, es decir, las restantes diez semanas, se flexibiliza notablemente, ya que podrá distribuirse a su voluntad en periodos semanales que podrán disfrutarse de forma acumulada o interrumpida desde la finalización de la suspensión obligatoria posterior al parto hasta que el hijo o la hija cumpla doce meses. Este periodo de suspensión del contrato, transcurridas las primeras seis semanas inmediatamente posteriores al parto, podrá disfrutarse, a su vez, en régimen de jornada completa o de jornada parcial, previo acuerdo entre la empresa y la persona trabajadora y conforme se determine reglamentariamente.

En definitiva, también son diversas las notas que definen el disfrute del resto del periodo de descanso para el cuidado del menor que corresponde al otro progenitor, es decir, las restantes diez semanas: es voluntario, por periodos semanales, puede disfrutarse de forma acumulada o interrumpida, puede disfrutarse desde la finalización de la suspensión obligatoria posterior al parto hasta que el hijo o la hija cumpla doce meses y, finalmente, puede disfrutarse a jornada completa o parcial.

Como puede observarse, estas características que se acaban de exponer se encuentran más orientadas a facilitar los derechos de conciliación y corresponsabilidad del otro progenitor $^{21}$.

En este contexto, no cabe duda que la supresión por parte del Real Decreto Ley 6/2019 del permiso por nacimiento de hijo previsto hasta el momento en el artículo 37.3.b) ET

\footnotetext{
${ }^{20}$ GORELli HERNÁNDEZ, Juan, "Hacia la corresponsabilidad..." cit. p. 283, mantiene al respecto que tiene mucho sentido que el otro progenitor deba disfrutar de una suspensión durante las primeras seis semanas cuando estamos ante un parto, pues durante dicho periodo la madre biológica debe recuperar su salud, lo que motiva la necesaria implicación del otro progenitor durante dicho periodo, si bien, parece que esta previsión responde más a la idea de equiparar lo más posible los periodos de suspensión de ambos progenitores, prueba de lo cual es que también en los casos de adopción, guarda o acogimiento existen estas seis semanas obligatorias.

${ }^{21}$ GORELLI HERNÁNDEZ, Juan, "Hacia la corresponsabilidad..." cit. p. 287, señala al respecto que una de las características de la nueva regulación es la introducción de una importante dosis de flexibilidad en el disfrute de la suspensión, favoreciendo que este derecho se adapte a las concretas necesidades de cada beneficiario.
} 
se debe a la consideración de que, tras la reforma introducida por dicha norma de la suspensión del contrato por nacimiento de hijo del otro progenitor, las finalidades antaño perseguidas por el referido permiso por nacimiento de hijo, a saber, que el padre acompañara a la madre en el alumbramiento y en los días posteriores al mismo, ahora han quedado perfectamente subsumidas en la actual configuración de esta causa de suspensión del contrato.

En esta línea parece encontrarse la STS de 27 de enero de 2021 (núm. rec. 188/2019), objeto de este comentario. A tal efecto, el Alto Tribunal pone de manifiesto que cuando se creó la causa de suspensión del contrato de trabajo por paternidad, la duración del mismo era muy inferior a la duración de la suspensión del contrato por maternidad, lo cual, explica que se mantuviera el permiso por nacimiento de dos días que se sumaba y relacionaba con la suspensión del contrato por paternidad. Por ello, desde la creación de la suspensión del contrato por paternidad, se dispuso siempre que la suspensión del contrato por paternidad se produciría "desde la finalización del permiso por nacimiento de hijo, previsto legal o convencionalmente", lo que, a criterio del Tribunal Supremo presuponía que el permiso por nacimiento de hijo "se tenía que disfrutar con anterioridad a la suspensión del contrato, debiendo hacerse, en concreto, en el momento del nacimiento del hijo".

Ello justifica, a criterio del Alto Tribunal, que con la equiparación a dieciséis semanas que lleva a cabo el Real Decreto-Ley 6/2019 de la duración de la suspensión del contrato prevista para ambos progenitores -madre biológica y progenitor distinto a ella-, se haya eliminado el permiso por nacimiento de hijo previsto hasta el momento en el artículo 37.3 b) ET. A criterio del Tribunal Supremo, si tras esta equiparación se hubiera mantenido el permiso por nacimiento de hijo "tan vinculado a la menor duración de la anterior suspensión del contrato por maternidad (...), se daría la paradoja de que el progenitor distinto de la madre biológica podría llegar a tener un periodo de tiempo de exoneración de la obligación de trabajar superior al de la propia madre biológica".

En definitiva, con esta argumentación, el Tribunal Supremo parte de la consideración de que en su día se incorporó al Estatuto de los Trabajadores el permiso de dos días por nacimiento de hijo, debido a que el progenitor distinto a la madre no tenía derecho a ningún día de suspensión del contrato por nacimiento de hijo y, posteriormente, aunque se fueran contemplando días de descanso por este motivo, siempre lo fue en un número muy inferior al que correspondía a la madre. Por el contrario, al incluirse una causa de suspensión del contrato del otro progenitor con reserva de puesto de trabajo, que mejora en mucho el permiso por nacimiento de hijo de dos días y de duración equiparable a la suspensión del contrato prevista para la madre, pierde el sentido el antiguo permiso por nacimiento de hijo, motivo por el que es eliminado del Estatuto de los Trabajadores y, 
por tanto, también parece perderlo cualquier mejora que al efecto hayan recogido los convenios colectivos.

En mi opinión, estos argumentos de fondo que atienden a la finalidad perseguida por el permiso por nacimiento de hijo, ahora subsumida en la suspensión del contrato por nacimiento y, en especial, en la equiparación de la duración de la misma para ambos progenitores que se ha llevado a cabo en el Real Decreto-Ley 6/2019, son los que se encuentran tras los argumentos aparentemente más formales esgrimidos por el Tribunal Supremo, consistentes en la vinculación prevista de forma expresa en el propio convenio colectivo entre el permiso fijado en el mismo y el previsto legalmente y en la imposibilidad de disfrutar ahora del permiso por nacimiento de hijo tras la fecha del parto, por encontrarse en ese momento el contrato del trabajador en suspenso de forma obligatoria durante las seis semanas posteriores al mismo por mandato legal.

No cabe duda de que estos argumentos más formales pueden resultar más discutibles y controvertidos, no en vano, nada impide a priori que los convenios colectivos puedan establecer nuevos permisos no previstos legalmente, además de mejorar los ya existentes, y también podría considerarse que el criterio que vincula el disfrute del permiso por nacimiento al momento mismo del parto y no a otro posterior se aleja de la doctrina elaborada por el propio Tribunal Supremo en relación con otros permisos, respecto de los que no se ha exigido con tanto rigor que se disfruten de forma inmediata al hecho causante de los mismos ${ }^{22}$.

A tal efecto, cabe destacar que la Audiencia Nacional, en todos los supuestos que ha analizado, ha llegado a soluciones diametralmente opuestas a las alcanzadas por el Tribunal Supremo en ambos aspectos, al considerar que los convenios colectivos pueden prever estos permisos por nacimiento de hijo como mejoras de forma totalmente autónoma e independiente a lo previsto por el Estatuto de los Trabajadores y que dichos permisos se pueden disfrutar con posterioridad al periodo de suspensión del contrato de trabajo por nacimiento. Pero es que incluso, la doctrina previa del Tribunal Supremo

\footnotetext{
${ }^{22}$ Vid., a título de ejemplo, STS de 13 de febrero de 2018 (núm. rec. 266/2016) y SSTS de 11 y 17 de marzo (núm. rec. 192/2018 y 193/2018, respectivamente). Vid. sobre esta materia, GONZÁLEZ GONZÁLEZ, Carlos, "La fecha inicial del disfrute de los permisos retribuidos. A propósito de la sentencia del Tribunal Supremo núm. 145/2018, de 13 de febrero", Revista Aranzadi Doctrinal, nº 7, 2018; LAHERA FORTEZA, Jesus, "Ejercicio y cómputo de los permisos retribuidos. Comentario a las Sentencias del Tribunal Supremo 229/2020 y 257/2020, de 11 y 17 de marzo", Revista de Trabajo y Seguridad Social. CEF, no 448, 220, MuÑoz Ruíz, Ana Belén, "Una revisión de los nuevos casos judiciales sobre el cómputo de los días de permisos retribuidos durante los periodos de descanso semanal y vacaciones", Trabajo y Derecho, $\mathrm{n}^{\circ}$ 71, 2020 y RiVAS VALLEJO, Pilar, "El cómputo de dies a quo en los permisos retribuidos en la jurisprudencia de la Sala cuarta del Tribunal Supremo: STS-SOC n 257/2020, de 12 de mayo", Revista de Jurisprudencia Laboral, $\mathrm{n}^{\circ}$ 6, 2020.
} 
parecía avalar esta posibilidad en su sentencia de 17 de enero de 2008 (núm. rec. 24/2007), en la que, como ya se ha indicado, se establecía que "para que una licencia que se ha creado y constituido como licencia por nacimiento de hijo (...), pueda ser disfrutada en fechas posteriores a ese alumbramiento (...), es de todo punto obligado que la norma que la estableció disponga expresa y claramente la posibilidad de ese disfrute tardio de la misma". Si bien, el propio Tribunal matizaba que "si tal norma no dice nada a tal respecto, no puede admitirse ni tener por válido este cumplimiento retrasado del permiso, pues es contrario, como se vio, a la verdadera naturaleza del mismo".

Esta interpretación, además, se podría ver reforzada por el hecho de que tras el Real Decreto-Ley 6/2019, el nacimiento comprende el parto y el cuidado del menor hasta los doce meses. Desde esta perspectiva, no se desnaturalizaría el permiso de nacimiento de origen convencional si se disfrutara dentro de ese período y, en cualquier caso, después de las semanas de descanso obligatorio. A tal efecto, si la finalidad del permiso concedido por el convenio colectivo es el cuidado del hijo (y no tanto el hecho concreto del nacimiento) podría defenderse el derecho no solo del otro progenitor (distinto de la madre, en caso de parto), sino también de la propia madre y, por supuesto, de ambos progenitores en caso de adopción.

A todo ello cabría sumar, finalmente, que nos encontramos ante una medida que, como ya ha indicado la Audiencia Nacional, tiene una indudable dimensión constitucional, no en vano, se encuentra directamente relacionada con los derechos de conciliación de la vida familiar y laboral y con el fomento de la corresponsabilidad entre hombres y mujeres. Por ello, la normativa aplicable, en este caso, las cláusulas convencionales reguladoras del permiso por nacimiento de hijo, deben ser interpretadas y aplicadas siempre del modo más favorable al efectivo ejercicio de los mismos ${ }^{23}$.

Precisamente, son los argumentos de fondo invocados por el Tribunal Supremo y no los argumentos más formales los que permiten augurar que, más allá de las características tan específicas de la previsión contenida en el artículo 30 del Convenio colectivo de la Sociedad Pública Eusko Trendibeak/Ferrocarriles Vascos, S.A que es objeto de análisis en este supuesto, la decisión del Alto Tribunal de no considerar vigente este permiso por nacimiento se puede extender a otros supuestos que puedan ser enjuiciados en el futuro.

\footnotetext{
${ }^{23}$ Aunque en relación con los permisos parentales, comparte esta visión la STJUE de 25 de febrero de 2021 (asunto C-129/20), al considerar que se trata de un derecho individual de capital importancia para lograr los objetivos anteriormente reseñados y que no puede ser objeto de una interpretación restrictiva, por lo que, concluye la Sala, "excluir a los padres que no trabajaban en el momento del nacimiento o de la adopción de su hijo equivaldría a limitar el derecho de estos progenitores a disfrutar de un permiso parental en un momento posterior de su vida en el que ejerzan de nuevo un empleo y en el que lo necesitarían para conciliar sus responsabilidades familiares y profesionales. Tal exclusión sería, por tanto, contraria al derecho individual de todo trabajador a disponer de un permiso parental".
} 
A tal efecto, cabe recordar que el referido artículo 30 del convenio colectivo contiene una mención expresa al permiso por nacimiento legalmente previsto en aquel momento y que establece de forma también expresa que el mismo deberá disfrutarse desde la fecha en que se produzca el parto, previsiones que no se contienen en otras cláusulas convencionales, que no contienen referencia expresa a la regulación legal del permiso por nacimiento del artículo 37.3 b) ET, ahora suprimida, ni fijan con tanta concreción el momento de disfrute del mismo tras el parto.

A esta previsión cabe añadir, además, la reflexión que se recoge en la sentencia del Tribunal Supremo de que el mantenimiento en estos supuestos del permiso por nacimiento de hijo previsto en el convenio colectivo, junto con la duración de dieciséis semanas de la suspensión del contrato por nacimiento ahora prevista por el Real Decreto $6 / 2019$, llevaría a la paradoja de que el progenitor distinto de la madre biológica podría llegar a tener un periodo de tiempo de exoneración de la obligación de trabajar superior al de la propia madre biológica.

No cabe duda que, tanto la equiparación del descanso por nacimiento que corresponde a los dos progenitores, como el sorprendente hecho de que, de admitirse la acumulación del permiso por nacimiento de hijo previsto en cada caso por el convenio colectivo con la duración de dieciséis semanas de la suspensión del contrato por nacimiento ahora prevista por el Real Decreto 6/2019, el progenitor distinto de la madre biológica podría llegar a tener un periodo de tiempo de exoneración de la obligación de trabajar superior al de la propia madre biológica, son circunstancias que también concurrirán al analizar cualquier otra cláusula convencional que prevea el derecho a un permiso por nacimiento de hijo con independencia de cuál sea su redactado y, en consecuencia, cabe pensar que su concurrencia llevará al Tribunal Supremo a adoptar una misma posición a la contenida en la STS de 27 de enero de 2021 (núm. rec. 188/2019) objeto de este comentario.

En este contexto, sin perjuicio de la más que probable modificación del régimen convencional a que pueden llegar las partes en el futuro, que atienda a la nueva situación originada por el Real Decreto 6/2019 y dadas las dudas que se pueden suscitar sobre la compatibilidad del permiso por nacimiento de hijo previsto en numerosos convenios colectivos con la equiparación del descanso por nacimiento que corresponde ahora a los dos progenitores, resulta muy recomendable la adopción de acuerdos entre las partes negociadoras de los referidos convenios colectivos que contribuyan a aclarar esta cuestión, dotándola de mayor seguridad jurídica. A título de ejemplo, encontramos el “Acuerdo relativo a la compatibilidad en el ámbito del IV Convenio Colectivo Único del permiso de dos días por nacimiento del artículo 75.b) con la suspensión de contrato por nacimiento del artículo 93.1". A tal efecto, dicho Acuerdo establece que "de lo anteriormente expuesto, se deriva la cuestión relativa a si son compatibles la suspensión 
del contrato y el permiso del IV Convenio colectivo único. En este sentido, el texto del IV CUAGE acordado recoge ambas figuras. El Real Decreto-Ley 6/2019 (...) es aprobado escasos días antes de la rúbrica del IV CUAGE. Ha de entenderse por seguridad jurídica que el acuerdo es posterior a la norma, de modo que la novedad legislativa no puede enervar este permiso; debiendo entenderse compatible con la suspensión del contrato del artículo 93.1 durante la vigencia del IV Convenio colectivo único, debiendo disfrutarse de manera inmediatamente seguida a la finalización de la suspensión del contrato".

\section{Bibliografía}

Alameda CASTilla, María Teresa, "Otro lento avance normativo hacia la corresponsabilidad familiar: suspensión del contrato de trabajo y prestación de paternidad", en Comentarios Laborales a la Ley de Igualdad entre Mujeres y Hombres, Tirant lo Blanch, Valencia, 2007.

BALleSter PASTOR, María Amparo, "El RDL 6/2019 para la garantía de la igualdad de trato y de oportunidades entre mujeres y hombres en el empleo y la ocupación: Dios y el Diablo en la tierra del sol”, Temas Laborales, nº 146, 2019.

CABERO MORÁn, Enrique, "La conversión de las situaciones de maternidad y paternidad en la de nacimiento y cuidado de menor por el principio de corresponsabilidad", Trabajo y Derecho, $\mathrm{n}^{\circ} 53,2019$.

CORDERo Gordillo, Vanesa, "La suspensión del contrato de trabajo por nacimiento de hijo o hija, adopción, guarda con fines de adopción y acogimiento tras el RDL 6/2019, de 1 de marzo", Revista Internacional y Comparada de Relaciones Laborales y Derecho del Empleo, volumen 7, n³ 3, 2019.

Fernández Collados, María Belén, "El permiso por paternidad como medida de conciliación de la vida familiar y laboral: aspectos críticos y propuestas de mejora", Revista Española de Derecho del Trabajo y de la Seguridad Social, nº 139, 2008.

Fernández Collados, María Belén, "La suspensión del contrato de trabajo por paternidad y el permiso retribuido por nacimiento de hijo: dos medidas de conciliación de la vida familiar y laboral, diferentes y compatibles", Revista Doctrinal Aranzadi Social, $\mathrm{n}^{\mathrm{o}}$ 3, 2009.

García Romero, Belén, "Permiso de maternidad adicional al legal reservado por el convenio colectivo a las madres trabajadoras: condiciones para su adecuación al Derecho 
de la Unión Europea en materia de igualdad de trato y no discriminación por razón de sexo", Revista de Jurisprudencia Laboral, n 1, 2021.

GonZÁlez GonZÁLEZ, Carlos, "La fecha inicial del disfrute de los permisos retribuidos. A propósito de la sentencia del Tribunal Supremo n ${ }^{\circ} 145,2018$, de 13 de febrero", Revista Aranzadi Doctrinal, $\mathrm{n}^{\mathrm{o}}$ 7, 2018.

Gorelli HeRnÁnDEZ, Juan, "Hacia la corresponsabilidad mediante la suspensión por nacimiento de hijos", Revista General del Derecho del Trabajo y de la Seguridad Social, $n^{\circ} 53,2019$.

LAHERA FORTEZA, Jesús, "Ejercicio y cómputo de los permisos retribuidos. Comentario a las Sentencias del Tribunal Supremo 229/2020 y 257/2020, de 11 y 17 de marzo", Revista de Trabajo y Seguridad Social. CEF, n 448, p. 220.

Lousada Arochena, José Fernando, Permiso de paternidad y conciliación masculina, Editorial Bomarzo, Albacete, 2008.

Martínez Moreno, Carolina y CAStro ArgüElles, María Ángeles, "La protección social de las situaciones de maternidad y paternidad”, en Moreneo PÉREZ, José Luís; Molina Navarrete, Cristóbal y Moreno VidA, María Nieves (Coords.), La Seguridad Social a la luz de las reformas pasadas, presentes y futuras: homenaje al profesor José Vida Soria con motivo de su jubilación, Ed. Comares, Granada, 2008.

Molina GonzÁlez-PumAriegA, Rocío Molina, "Un paso más hacia la corresponsabilidad real: la suspensión del contrato de trabajo por nacimiento de hijo o hija, por adopción, guarda con fines de adopción y acogimiento tras el Real Decreto-Ley 6/2019”, Derecho Social y Empresa, nº 12, 2020.

Molins García-ATANCE, Juan, "La reforma de las prestaciones de maternidad y paternidad por la Ley Orgánica para la igualdad efectiva de mujeres y hombres", Revista del Ministerio de Trabajo y Asuntos Sociales, no 79, 2009.

MoReno GenÉ, Josep, “De la suspensión del contrato por paternidad a la suspensión del contrato del otro progenitor por nacimiento de hijo ¿un paso definitivo hacia la corresponsabilidad?", Nueva Revista Española de Derecho del Trabajo, nº 227, 2020.

Moreno Gené, Josep, "La suspensión del contrato de trabajo y la prestación por paternidad de los trabajadores por cuenta ajena diez años después de la aprobación de la Ley de Igualdad”, en Romero Burillo, Ana María (Dira. y Coorda.) y RodríGuez 
Orgaz, Cristina. (Coorda.): Trabajo, Género e Igualdad. Un estudio jurídico-laboral tras diez años de la aprobación de la LO 3/2007 para la igualdad efectiva de mujeres y hombres, Thomson Reuters Aranzadi, Cizur Menor (Navarra), 2018.

MuÑoz Ruíz, Ana Belén, "Una revisión de los nuevos casos judiciales sobre el cómputo de los días de permisos retribuidos durante los periodos de descanso semanal y vacaciones", Trabajo y Derecho, $\mathrm{n}^{\mathrm{o}} 71,2020$.

NúÑEZ-Cortés Contreras, Pilar y Garrigues Giménez, Amparo, "El permiso y la prestación por paternidad en la Ley Orgánica para la Igualdad”, Revista de Trabajo y Seguridad Social. CEF, no 300, 2008.

PASTOR MARTíneZ, Albert, "Las medidas laborales del Real Decreto-Ley 6/2019, de 1 de marzo de medidas urgentes para garantía de la igualdad de trato y de oportunidades entre mujeres y hombres en el empleo y la ocupación: un paso hacia la efectividad de la igualdad de trato y oportunidades desde la corresponsabilidad", IUSlabor, nº 1, 2019.

Pedrajas Moreno, Abdón y SAla Franco, Tomás, La protección de la maternidad, la paternidad y la adopción y acogimiento, Tirant lo Blanch, Valencia, 2008.

PERÁn QueSADA, Salvador, "De la tutela diferenciada de la maternidad y la paternidad a la protección por nacimiento y cuidado de menor desde una perspectiva constitucional", Revista de Derecho de la Seguridad Social, no 20, 2019.

PÉRez CAstillo, Ana María, "La prestación por paternidad en los casos de paternidad biológica, adopción y acogimiento. Análisis crítico", Revista del Ministerio de Trabajo y Asuntos Sociales, ${ }^{\circ}$ Extra 3, 2007.

Rivas VAllejo, Pilar, "El cómputo de dies a quo en los permisos retribuidos en la jurisprudencia de la Sala cuarta del Tribunal Supremo: STS-SOC n ${ }^{\circ}$ 257/2020, de 12 de mayo", Revista de Jurisprudencia Laboral, nº 6, 2020. 